\title{
Bangladesh Imports Tea despite Being an Age-Old Tea Exporting Country
}

\author{
Professor Mohammad Lutfar Rahman ${ }^{1}$, Professor Dr Harwindar Singh ${ }^{2}$, Dr Khairir Khalil ${ }^{3}$ \\ ${ }^{I}$ Professor and Registrar, IUBAT-International University of Business Agriculture and Technology \\ ${ }^{2}$ Associate Professor, School of Business, Malaysia University of Science and Technology \\ ${ }^{3}$ School of Business, Malaysia University of Science and Technology
}

\begin{abstract}
Tea consumption in Bangladesh is increasing 3 percent per annum but its production is increasing 1 percent only. Due to not increasing tea production with the pace of increase in consumption, the title of Bangladesh as a tea exporting country has already been changed to a tea importing country costing at least US\$ 70 million annually importing 30 million $\mathrm{kg}$ tea to meet the deficit every year. Country may save the hard-earned foreign exchange through increase in tea production from present 85 million $\mathrm{kg}$ to 120 million $\mathrm{kg}$ in order to stop importing tea, rather export tea utilizing every hectare garden land under tea plantation properly to increase yield per hectare from present $1500 \mathrm{~kg}$ to $2500 \mathrm{~kg}$ per hectare.
\end{abstract}

\section{INTRODUCTION}

B angladesh is about to embrace the fate of certain diminish of its pride as a major tea exporting country which is quite similar with the one happened to its sugar industry once. The country which once used to export $90 \%$ of its tea is likely to experience reversal of the trend. Soaring consumption at home and sluggish production have all but ended 150 years of outbound journey for the widely-consumed beverage. Bangladesh saw the tea export volume coming down to $0.5 \%$ in recent years leading to an end of the era of competition with the tea giants such as Kenya, India and Sri Lanka. In the 1990s, Bangladesh was the 5th largest exporter of tea, but a major boost in demand eliminated the surplus. The paltry amount of exports is still made for the sake of some longtrusted and entrenched customers mainly in Pakistan and the Middle East. Total domestic consumption is around 80 million kilograms against a total production of somewhat above 85 million kilograms. The domestic consumption is abruptly increasing at rate of $3 \%$ per annum against a slowmoving rate of production at $1 \%$ per annum. Incessant loss of edge in tea exports is not the only consequence derived by the growth in domestic consumption but the failure in keeping pace with the productivity comparing to the neighbor countries. Per hector yield of Sri Lanka and India were around 2200 and 2100 kilogram respectively in 2018 where in Bangladesh it was recorded slightly above 1400 kilogram per hector. As a result of unhealthy yield per hector, manufacturing cost of per kilogram tea has gone up allowing the outsiders to do business in Bangladesh through the blessing of open economy. Insufficient investment which was only $3.80 \%$ has interrupted the growth badly in last decade while poor management in tea plantation expatiated the fall of industry. To resuscitate the industry, additional cultivable areas were explored but all went in vain due to lack of scientific approach and enduring the age-old tradition of farming and manufacturing. Bangladesh has 164 tea estates covering total grant area of 100000 hectare of land of which $49 \%$ remains unutilized. The present momentum tends to put a catastrophic impact on GDP along with costing 70 million US\$ to be used for importing around 30 million kilogram of tea in order to meet the terrible deficit in domestic demand. To stabilize the price and satisfy the terrific increment of internal demand, low quality tea with substandard flavor has entered the market which made the situation worse as weekly international auction at Chittagong witnesses' withdrawal of premiere good quality tea for lack of local and foreign buyers.

\section{OBJECTIVE}

The paper aims at:

i. Examination of the present status of production, domestic consumption and export of tea of the country;

ii. Exploration of the prospect of new areas for tea production; and

iii. Policy measures to increase production and export as well as quality improvement, and roles to be played by the government and national bodies.

\section{HOME CONSUMPTION MOUNTS}

Tea in Bangladesh was mainly for export oriented in the past. As a result of increased population growth with tea drinking habit and rapid urbanization, domestic consumption has been soaring at about@ @ $3 \%$ per annum. Only recently has the industry been able to match the local demand with record-high productions in the past three years. By adopting new agricultural practices and expanding the range of tea products produced, Bangladesh is set to meet local demand fully and if production increase goes in this trend, Bangladesh will be a tea export earner once again. 


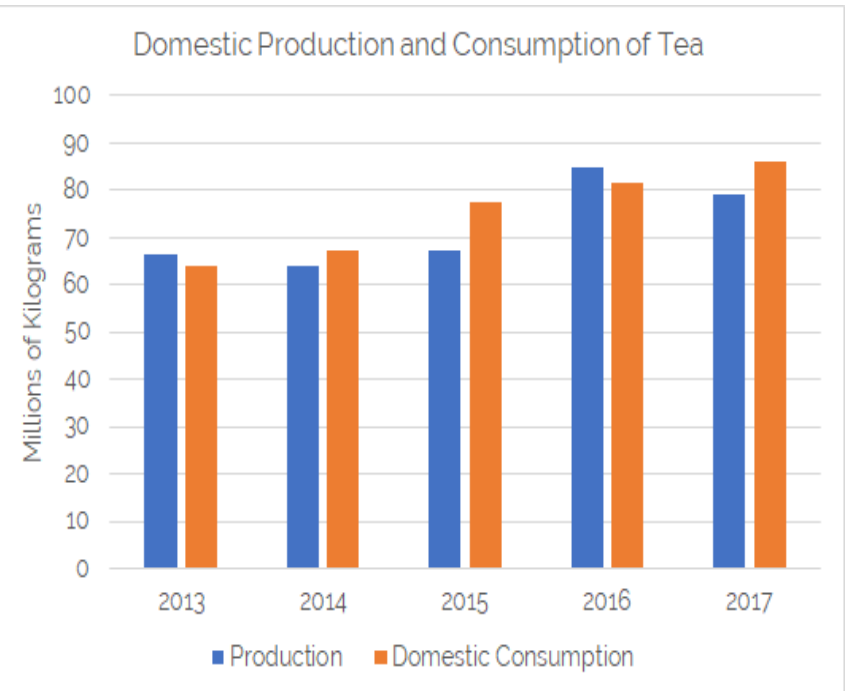

Graph 1 shows escalating home consumption corresponding to tea production

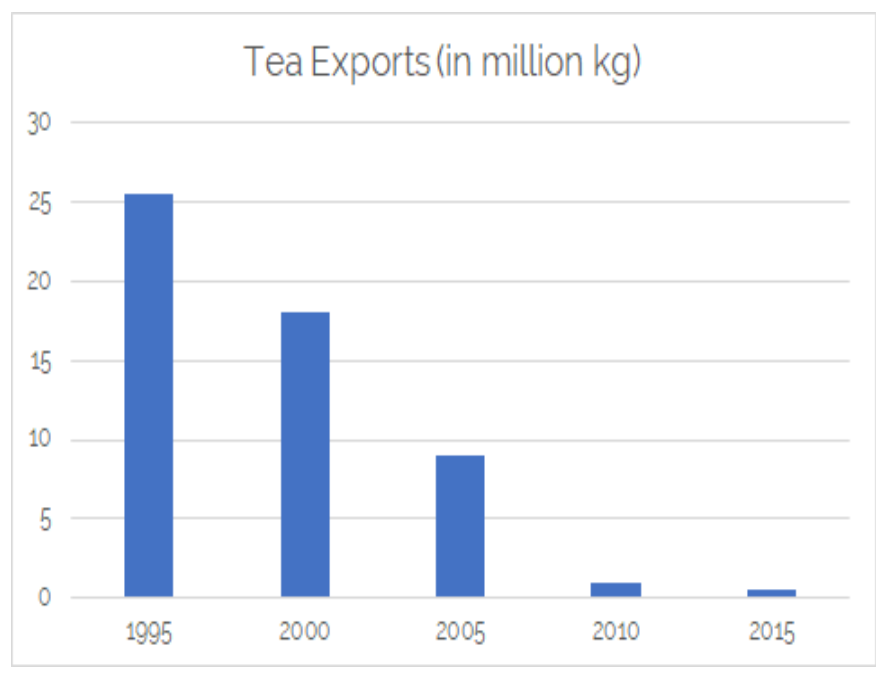

Graph 2 shows tea export from Bangladesh almost nil

\section{Fallow Lands Remain Idle:}

Currently the industry is approaching roughly with an average yield of 1240 kilogram per hector with $49 \%$ of total cultivable lands being unutilized which indicates thatnearly half of potential lands are being left as fallow. Of course, in this $49 \%$ unutilized land in the tea estates, factory, labor shed, bungalows, paddy field, forest, streams are situated which are part and parcel of tea garden. On the other hand, the country possesses vast farmable area which can be extended to tea plantation. It is estimated that nearly 6,106 hector suitable land is accessible in 164 tea estates for new extension in the left over 50000-hectare grant area out of total grant area of 100000 hectare.It has become crucial to formulate some policies in order to explore the likelihoods of establishing small holding for tea plantations in the suitable areas of the country. A study unveiled that soil and climatic factors of Panchagarh and all the three hill districts have been found scientifically suitable for cultivation of tea. Avoiding all legal obligations, still it is possible to bring near 35,000 ha in
Panchagarh, 46,875 ha in three hill districts of Chittagong and 3,500 ha in age old tea areas of greater Sylhet and greater Chittagong under tea cultivation in the form of small holdings. The extension of that study also uncovered that 4455 ha of land in Thakurgaon, 4,067 ha in greater Mymensingh, and 7822 ha in Chittagong and Cox's Bazar districts are suitable for small holding tea cultivation. Moreover, a substantial number of populations living under poverty line in these regions could be gainfully self-employed in small holding tea plantations.

\section{Old Plants Produce Bare Outcome:}

The orthodox methods used in manufacturing process have largely been replaced with the CTC. (Crush, Tear, and Curl) is a method, used to process black tea. To sustain a gainful output with quality tea, the industry had deployed the method but it hardly made any change in yield per hector as the reason was less likely involved in the process of manufacture but the outcome from the planted tree. Though Bangladesh has 164 tea estates covering about 50000 hectares under tea cultivation they are plucking tea leaves from $50 \%$ old plants that produce low yield per hector. Bangladesh has potential to produce approximately 100million kilogram tea annually by 2025 by adopting the policy of massive infilling, block infilling and replacement replanting the aged and uneconomic tea that yields only $495 \mathrm{~kg} / \mathrm{ha}$ with improved varieties and can bring yield per hectare $1500 \mathrm{~kg}$. It has already been discussed that only $50 \%$ of total land area are remaining unutilized for not being suitable for tea plantation and for mandatory utilization of land for other purpose such as paddy land, factory, bungalow, playground, graveyard, labor line etc.

\section{Administration Makes A Mess:}

As the ministry of commerce is concern about the fair price of commodity, they are not imposing any excessive supplementary duty to discourage the imports while Sri Lanka and India have imposed more than $100 \%$ supplementary duty as they have well-structured industry, capable of producing good quality tea. Due to imposing nominal duty for tea import by our government, unscrupulous importers import substandard tea from abroad and smugglers resort to bring undocumented tea across border resulting in crisis of buyers for our genuine tea in auction which remain unsold creating additional cost for warehouse rent. This is absolutely a threat to the genuine tea growers. It is not that climate and industry of Bangladesh is not suitable to produce world class tea but the pre-production tea processing in the factory have made it difficult to reach standard quality with reasonable expenditure. A very decent plucking of leaves is required to make the first stage of tea leaves processing healthier to get a quality output but workers are involved with resorting to rough plucking in order to receive some monetary gains in leaf weighment and weekly wages but ultimate loss counted by owner for producing substandard tea from rough plucking sold at discounted rate or face withdrawal in international tea auction.It is crucial that from the very beginning of plucking 
to packaging, the entire manufacturing process goes through some well-defined sequences and time shafts but that reality is a bit different, as existing process causes remarkable delay from steps to steps due to break down of machinery and produces low quality tea. Production cost for each factor like power and fuel, spares and stores, chest, freight, warehousing, fertilizer, insecticide, repairs and maintenance has augmented. Weeds in lands, insufficient fertilizer, absence of shade, shortage of drainage facilities including faulty pruning, pests and disease reduce tea production by nearly $22 \%$ each year. Less capacity and inefficiency of backdated machines with grater consumption of power and high depreciation cost is also contributing to increase the price.

\section{Concept of Small Holding:}

The tea plantation in Indonesia mostly belong to estates. They are also responsible for developing farmers at surrounding area. A program namely "core-nucleus project" are used to be implemented by involving farmers to plant crops with technical and financial aid provided by estates and the yield is sold to estate at certain price level based on affordable quality. (Yuliando et al. 2015). Although small holding tea plantation has been started in northern Bangladesh since 2001, unlike Indonesia there is no record of any of our major tea estate has done any nucleus project for small holding. But small holding in Panchagarh district and adjoining areas are contributing GDP significantly to the national exchequer by producing about 10-million-kilogram tea annually. The small holdings their needs government patronization of availing Agri-loan, maximum price at the bought leaf factory for selling their cultivated green leaf. A study unveiled that soil and climatic factors of Panchagarh and all the three hill districts have been found scientifically suitable for cultivation of tea. Establishment of small tea gardens will bring a sustainable improvement in the socioeconomic condition in those areas. More manufacturing facilities will be set up to help processing of green leaf, improve trade and other logistic services will also help to meet the internal demand and maintain an exportable surplus. Moreover, asubstantial number of populations living under poverty line in these regions could be gainfully self-employed in small holding tea plantations.

\section{CONCLUSION}

Tea in Bangladesh was mainly for export oriented in the past. As a result of increased population growth with tea drinking habit and rapid urbanization, domestic consumption has been soaring at about@ @ 3\% per annum. Only recently has the industry been able to match the local demand with record-high productions in the past three years. By adopting new agricultural practices and expanding the range of tea products produced, Bangladesh is set to meet local demand fully and if production increase goes in this trend, Bangladesh will be a tea export earner once again.

Bangladesh tea had a captive export market in few countries of the world and the country was quite comfortable by exporting tea to those countries without many endeavors. The scenario has changed in recent years because of soaring home consumption, meagre rate of production increase, open market economy, emergence of new entrants in world tea market with low priced tea, trade and tariff barriers and inadequate promotional activities. Once home consumption is met with 75 million kilo tea, Bangladesh may revive its tea market for export in countries like Pakistan, Poland, Afghanistan without any hindrance with excess production which now reached 90 million kilos. Because tea importers of those countries used to import Bangladesh tea from time immemorial till eighties of last century when home consumption at Bangladesh reached the peak of total tea production. Many traders in those countries are so expert in handling Bangladesh tea that they were able to pronounce the name of the tea garden wherefrom tea has come. 